\title{
PEP III News and Plans
}

1. PEP III Conference in Aix-enProvence, August 27-31, 2001. The conference will have keynote presentations combined with posters. There is excellent poster space at the Conference Center and we plan to organize posters into PEP III themes and into national and international projects. Consult the web page (http://www.geog.ucl.ac.uk/ecrcl pep3/) for details and updates.

2. ESF Programme "Holocene Climate Variability (HOLIVAR)". We have made an application to the European Science Foundation for a 5 year program to bring the time-stream I component of PEP III together and to make connections with the climate modeling community. If the proposal is successful, the starting date would be January $1^{\text {st }}, 2001$. The first workshop might then be held in association with the Aix conference in August 2001. The proposal includes costings for annual workshops (5) and training courses (2). Unfor- tunately the ESF will not fund scientists from countries outside the member states, but the PAGES office in Bern will consider applications for funding East European and African members of the PEP III community on a workshop by workshop basis.

3. Development of a Multi-Proxy Database is an essential part of the PEP III strategy and discussions are under way as to the most appropriate strategy.

4. National and regional meetings Many countries now have PAGES/ PEP III groups and some have been holding meetings. More PEP III-related meetings are planned in the coming year (e.g. Nigeria, Czech Republic, Germany). And there are also plans to have regional meetings to discuss results in advance of the Aix conference. Please keep us informed of new plans and we can make sure these are posted on the PEP III web page.
5. A key forthcoming meeting for PEP III African scientists is a meeting on November 13-16 in Enugu, Nigeria on Holocene environments in sub-Saharan Africa. This meeting is organized by Chioiri Agwu (EPSEELON@aol.com) who can supply more details.

6. Publicity - In addition to the web site we now have PEP III flyers and a large PEP III laminated poster available. We can send flyers in the post and the poster can be downloaded from the web page. Please contact Cathy Stickley for help and information.

\section{Rick Battarbee and Catherine Stickley}

ECRC, Dept. Geography, University College London, UK

rbattarb@geography.ucl.ac.uk

c.stickley@ucl.ac.uk

\section{Françoise Gasse}

CEREGE, CNRS, Université d'Aix-Marseille III, Aix-enProvence, France gasse@cerege.fr

\section{ANNOUNCING THE FIRST}

\section{PAGES - PEP III CONFERENCE}

\section{Past Climate Variability in Europe and Africa}

\section{8-22 September, 2001, Les Centres de Congrès, Aix-en-Provence, FRANCE}

PAGES - PEPIII is concerned with studies of past climate variability in Europe and Africa. Key aims are to assess variability on different time-scales, to assess the impacts of past climate change on natural ecosystems and human society, and to provide a firm basis for the verification and testing of climate models.

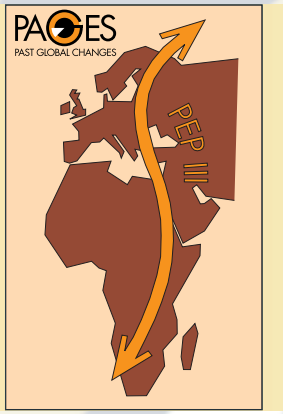

This conference will present the latest results of current research programmes and summarise our present knowledge of the climate system and its natural variability in Europe and Africa.

There will be a number of plenary lectures from invited speakers and a series of poster sessions open for all participants, plus a post-conference excursion to the Massif Central, France (subject to interest).

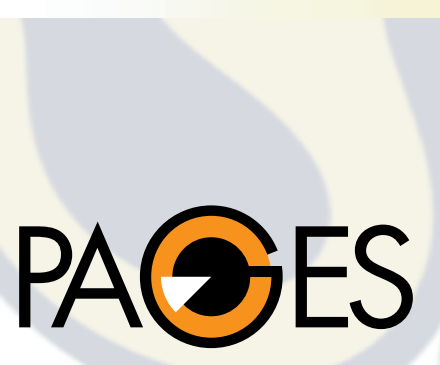

To register your interest* and enrol on our mailing list, please contact:

Dr. Catherine Stickley

Environmental Change Research Centre (ECRC) University College London, 26 Bedford Way London WCIH OAP, UK

$\mathrm{T}:+44(0) 2076795562 \mathrm{~F}:+44(0) 2073877565$ c.stickley@ucl.ac.uk I http://www.geog.ucl.ac.uk/ecrc/pep3/

*Please indicate if you would like to present a poster 